Original Research Paper

\title{
ELISA-Based Development of Functional Antibodies for the Efficient Detection of Mycotoxigenic Fusarium (F. oxysporum and $F$. circinatum) and Diplodia (D. pinea) Species
}

\author{
${ }^{1}$ Phumzile Mkhize and ${ }^{2}$ Phetole Mangena \\ ${ }^{1}$ Department of Biochemistry, Microbiology and Biotechnology, School of Molecular and Life Sciences, \\ Faculty of Science and Agriculture, University of Limpopo, Private Bag X1106, Sovenga, 0727, Republic of South Africa \\ ${ }^{2}$ Department of Biodiversity, School of Molecular and Life Sciences, Faculty of Science and Agriculture, \\ University of Limpopo, Private Bag X1106, Sovenga, 0727, Republic of South Africa
}

\begin{abstract}
Article history
Received: 23-08-2020

Revised: 09-11-2020

Accepted: 18-11-2020

Corresponding Author:

Phetole Mangena

Department of Biodiversity,

School of Molecular and Life

Sciences, Faculty of Science and Agriculture, University of Limpopo, Private Bag X1106, Sovenga, 0727, Republic of South Africa

Email: phetole.mangena@ul.ac.za
\end{abstract}

\begin{abstract}
Fusarium contains the most toxigenic and important fungal pathogens, producing a wide range of mycotoxins that include the more toxic secondary metabolites called fumonisins. This study analyzed the presence of common exo- and mycelium-soluble antigens, purified proteins using reducing SDS-PAGE and the expression of antibodies against different fungal pathogens. The results showed the presence of common antigens between pathogens and development of antibodies against antigens from $F$. circinatum, $F$. oxysporum and $D$. pinea. A strong reactivity against the antigens ranged between 0.510 to 0.868 in $F$. circinatum and $F$. oxysporum isolates. The reactivity of anti- $D$. pinea antibodies was relatively low, with the highest absorbance value of 0.650 , accompanied by a minimal cross reactivity. Overall, these findings indicated that, antibodies against mycelium-soluble antigens were the most immunoreactive and could be helpful for the development of a rapid Fusarium detection tool for use in various industries.
\end{abstract}

Keywords: Antibodies, Antigens, ELISA, Fusarium, SDS-PAGE, Western Blotting

\section{Introduction}

Fusarium contain the most toxigenic and important fungal pathogens, producing a wide range of mycotoxins, including the more toxic secondary metabolites called fumonisins (Bubici et al., 2019). The mycotoxins produced by these organisms are often associated with plant, animal and human diseases (Nelson et al., 1994). Storer et al. (2002; Bubici et al., 2019) reported more than 17 Fusarium species that target numerous cultivated trees, grain and cereal crops, causing a decrease in the quality and quantity of yield attributes. Amongst them, Fusarium circinatum, Fusarium oxysporum, Fusarium solani and Fusarium culmorum were some of the widely implicated species, in the decreased growth and productivity of many cultivated timber, medicinal and crop species (Bailey and Lazarorits, 2003; Adesina et al., 2009; Bubici et al., 2019). As a result of these effects, Fusarium species have a considerable impact on ecological, economic and social dynamics of the millions of people around the world. These fungal pathogens cause reduction in the growth of agro economically important plant species by causing pitch canker, wilts (especially in seedlings), gibberella ear rot, crown rot and head blight, as well as other symptoms/toxigenic effects seen in a number of crops including pine trees, sorghum, maize and wheat (Gordon et al., 2015; Beukes et al., 2017).

Therefore, early pathogen detection and identification of the toxigenic symptoms will play a major role in ensuring efficient and proper control, limiting the spread of the disease. With fungal pathogens still identified using conventional methods such as the investigation of visible symptoms, use of selective media and microscopic analysis. More accurately sensitive, rapid and reliable novel protocols still need to be developed, especially where quick detections are required. Such methods include the use of nucleic acid based detection using Polymerase Chain Reaction (PCR) and protein based immunochemical techniques (Zhao et al., 2014; Sue et al., 2014; Kuzdraliński et al., 2017; Springer et al., 
2019). The use of immunochemical detection system entailing Enzyme-Linked Immunosorbent Assay (ELISA) offer a much more sensitive detection with shorter analytical time and lower detection limit, particularly when coupled with real-time PCR (Sue et al., 2014).

Thus, the development of functional antibodies against Fusarium remain of significant interest in preventing the negative impacts of Fusarium-associated mycotoxins. The objective of the current paper was to investigate the development of specific functional antibodies against Fusarium antigens isolated from $D$. pinea, $F$. circinatum and $F$. oxysporum for potential use as a detection tool in various industries such as veterinary, medical and agricultural sector.

\section{Materials and Methods}

\section{Diplodia sp. and Fusarium spp. Culture}

Diplodia pinea, Fusarium circinatum and Fusarium oxysporum isolates were sourced from the Forestry and Agricultural Biotechnology Institute, at the University of Pretoria, Republic of South Africa. Fungal isolates were first cultured on potato dextrose agar for 14 days at $28^{\circ} \mathrm{C}$ for antigen preparation as described by (Gan et al., 1997). Culture-plugs were excised out of the agar plates, inoculated in $100 \mathrm{~mL}$ nutrient broth containing $1 \%(\mathrm{w} / \mathrm{v})$ yeast extract in combination with $1 \%(\mathrm{w} / \mathrm{v})$ dextrose and incubated under similar conditions with constant agitation. Mycelia broth culture was filtered using a cheesecloth to separate the filtrate exo-antigen from mycelial pads. Mycelial pads were then resuspended in Phosphate Buffer Saline (PBS) comprising of $0.8 \%$ (w/v) $\quad \mathrm{NaCl}, \quad 0.02 \% \quad(\mathrm{w} / \mathrm{v}) \quad \mathrm{KCl}, \quad 0.115 \% \quad$ (w/v) $\mathrm{Na}_{2} \mathrm{HPO}_{4} .2 \mathrm{H}_{2} \mathrm{O}$ and $0.02 \%$ (w/v) $\mathrm{KH}_{2} \mathrm{PO}_{4}$. The mixture was homogenized for $5 \mathrm{~min}$, briefly sonicated and centrifuged at $14,000 \mathrm{xg}$ for $5 \mathrm{~min}$ at room temperature. Mycelium-soluble-antigen culture supernatant was then collected and stored at $-20^{\circ} \mathrm{C}$ until used for protein analysis. However, the exo-antigen filtrates were resuspended on PBS buffer, sonicated and dialyzed overnight using dialysis tubing with a molecular cut-off of 12-14 kDa. Dialysis tubing was then placed in PEG 20000 for $20 \mathrm{~min}$ to concentrate the exo-antigen proteins.

\section{Antigen Preparation from SDS-PAGE Separated Proteins}

Proteins in exo-antigen and mycelium-soluble antigens were first concentrated using the $\mathrm{BCA}^{\mathrm{TM}}$ Protein Assay Kit (Pierce, Rockford, IL, USA). A standard curve was constructed using Bovine Serum Albumin (BSA) at 0.0025-2 mg. $\mathrm{ml}^{-1}$ to determine the antigen concentration (Fig. 1A). Antigen samples were mixed with working reagent at $1: 20$ ratio and incubated at $37^{\circ} \mathrm{C}$ for $30 \mathrm{~min}$ and then a color change was measured at $562 \mathrm{~nm}$ using a
FLUORStar Optima spectrophotometer (BMG Labtech, Offenburg, Germany).

Analysis and selection of unique protein bands for each pathogen was conducted through $10 \%$ reducing Sodium Dodecyl Sulfate-Polyacrylamide Gel Electrophoresis (SDSPAGE), according to (Laemmli, 1970). A total of 20 $\mu \mathrm{g} \cdot \mathrm{ml}^{-1}$ of each mycelium-soluble and exo- antigen samples were individually mixed in reducing sample buffer ( $\mathrm{pH}$ 6.8) containing $125 \mathrm{mM}$ Tris- $\mathrm{HCl}, 4 \%$ (w/v) SDS, $20 \%$ (v/v) glycerol and $10 \%$ (v/v) 2mercaptoethanol. The mixtures were heated at $100^{\circ} \mathrm{C}$ for $5 \mathrm{~min}$, loaded in SDS-PAGE gel wells $(20 \mu \mathrm{g}$ per well) and then separated at constant current (18 mA per gel) until loading dye reach the bottom of the gel. Molecular marker comprising of bovine serum albumin (68 $\mathrm{kDa})$, ovalbumin (45 kDa), carbonic anhydrase $(30 \mathrm{kDa})$ and lysozyme $(14 \mathrm{kDa})$ were loaded on the first well of each gel. Unique and consistent bands observed from different gel runs were selected for purification. All gels were stained using a solution containing $0.125 \% \quad(\mathrm{w} / \mathrm{v})$ Coomassie Blue- R250, 50\% (v/v) methanol and 10\% $(\mathrm{v} / \mathrm{v})$ acetic acid for four hours and distained using acetic acid-methanol-water solution at 50:165:785 ratio.

\section{Antibody Isolation from Egg Laying Chickens}

Isolation of pre-immune antibodies were carried out from eggs of chickens before immunization. Two chickens were required for each antigen and five antigens were then used to raise antibodies. Each antigen was mixed with an equal volume of Freund's complete adjuvant for the first injection and Freund's incomplete adjuvant was administered on at two-week interval as booster injections. A Polyethylene Glycol (PEG) precipitation method as described by (Polson et al., 1985) was used for antibody isolation. The pellet containing $\operatorname{IgY}$ was suspended in the isolation buffer containing $1.56 \%(\mathrm{w} / \mathrm{v}) \mathrm{NaH}_{2} \mathrm{PO}_{4} .2 \mathrm{H}_{2} \mathrm{O}, 0.02 \%$ (w/v) $\mathrm{NaN}_{3}$ titrated to $\mathrm{pH} 7.6$ with $\mathrm{NaOH}$ and in a 1/6th volume of yolk. A $10 \%(\mathrm{w} / \mathrm{v})$ sodium azide solution was added to the final concentration of $0.1 \%(\mathrm{w} / \mathrm{v})$ and the mixture was stored at $4^{\circ} \mathrm{C}$.

\section{Preparation of ELISA and Cross-Reactive Test}

An indirect ELISA was used for evaluation of antibody production over time and in cross-reactivity tests as indicated in Fig. 1B. The microtiter plates were coated with $100 \mu \mathrm{g} \cdot \mathrm{ml}^{-1}$ antigen in PBS at $37^{\circ} \mathrm{C}$ for $2 \mathrm{~h}$ followed by $4^{\circ} \mathrm{C}$ overnight. Blocking of unoccupied sites in wells was done by adding $200 \mu \mathrm{L} \mathrm{BSA}(0.5 \%$, w/v in PBS) for $1 \mathrm{~h}$ at $37^{\circ} \mathrm{C}$. Microtiter plates were washed a few minutes with PBS containing $0.1 \%$ (v/v) Tween 20 and $10 \mu \mathrm{g} \cdot \mathrm{ml}^{-1}$ of primary antibody in BSA specific for each pathogen added and then incubated for $2 \mathrm{~h}$ at $37^{\circ} \mathrm{C}$. Rabbit antichicken IgY-horse radish peroxidase conjugate was added to the wells and incubated for $1 \mathrm{~h}$ at $37^{\circ} \mathrm{C}$. 

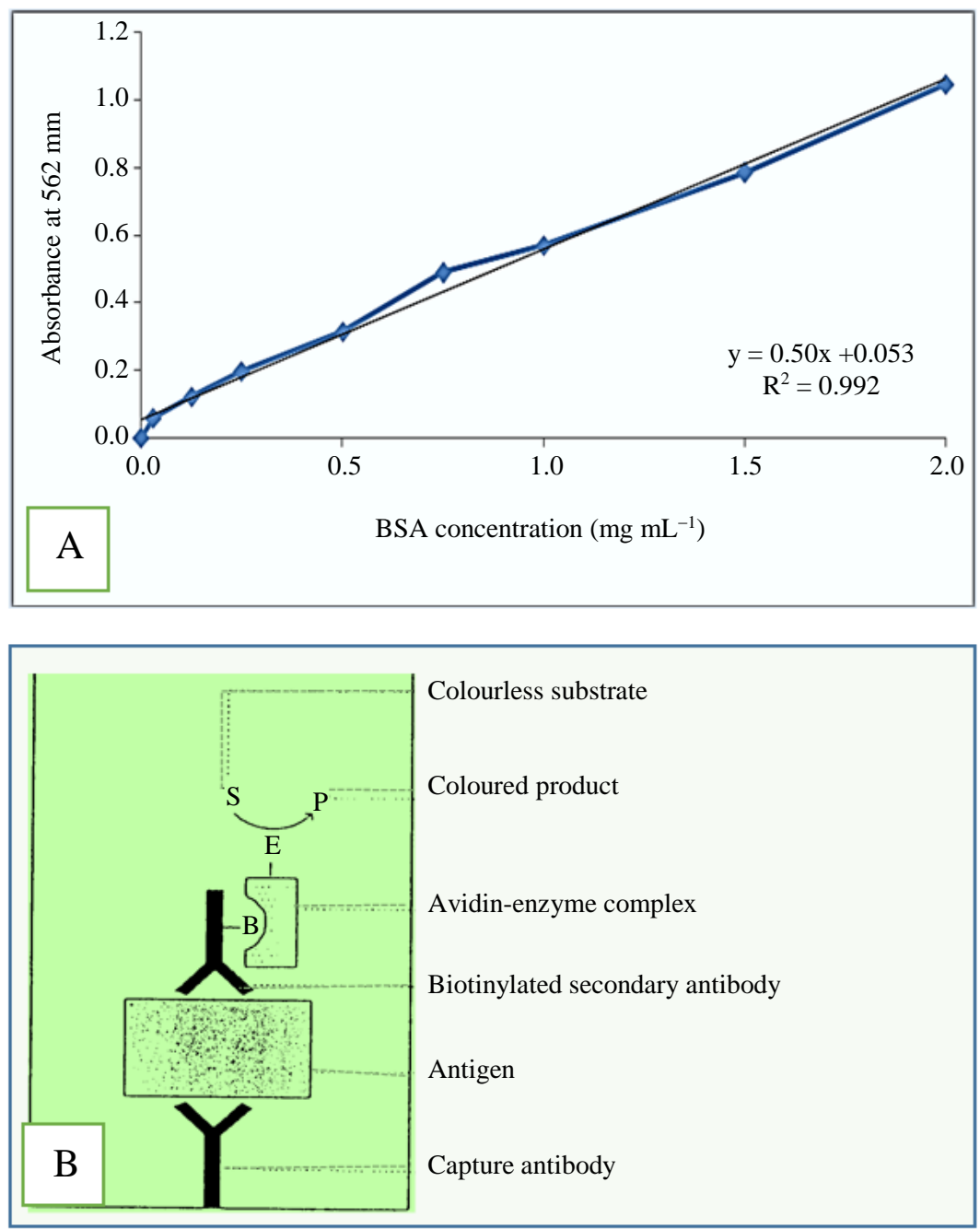

Fig. 1: Standard curve for BCA protein quantification assay of BSA known concentration $\left(0.025-2.0 \mathrm{mg} \cdot \mathrm{ml}^{-1}\right)$ measured at $562 \mathrm{~nm}$ (A) and common indirect ELISA format used in the development of Fusarium detection methods (B)

The plates were washed and ABTS substrate solution [0.05\% (w/v) ABTS and $0.0015 \%(\mathrm{v} / \mathrm{v}) \mathrm{H}_{2} \mathrm{O}_{2}$ in citratephosphate buffer, $\mathrm{pH}$ 5.0] containing $\mathrm{H}_{2} \mathrm{O}_{2}$ added and incubated for $10 \mathrm{~min}$ at room temperature. After incubation, the absorbance was measured at $405 \mathrm{~nm}$ using a FLUORStar Optima Spectrophotometer.

Antibody cross-reactivity was evaluated using indirect ELISA. A $10 \mu \mathrm{g} \cdot \mathrm{ml}^{-1}$ protein was used for each antibody. Five microtiter plates were set out for crossreactivity and each plate contained one set of antigen used for coating. The plates were treated as indicated above, where five antibodies were used for each antigen and color changes after the addition of ABTS substrate solution were measured at $405 \mathrm{~nm}$.

\section{Western Blotting for Analysis of Antigen Reactivity}

For analysis of antigen reactivity, mycelium-soluble antigen for $D$. pinea, $F$. circinatum and $F$. oxysporum were separated on reducing SDS-PAGE gels in duplicates and stained with Coomassie Blue to view original protein patterns and for protein transfer to the nitrocellulose membrane as described by (Towbin et al., 1979). Protein gels, filter paper rectangles and nitrocellulose membrane were cut and immersed into blotting buffer prepared with $0.6 \%$ (w/v) Tris-HCl, $1.44 \% \quad(\mathrm{w} / \mathrm{v})$ glycine, $20 \% \quad(\mathrm{v} / \mathrm{v})$ methanol and supplemented with $4.5 \mathrm{~mL}$ of $10 \%$ SDS solution before use. Filter paper rectangles and nitrocellulose membrane were placed on the surface of the blotting buffer. Protein gels were placed on top of nitrocellulose membranes and additional filter paper sheets were then used to cover the gels (Towbin et al., 1979).

Blotting was conducted at $40 \mathrm{~mA}$ for $16 \mathrm{~h}$ using a wet blotter (Bio-Rad Hercules, CA, USA) in transfer buffer (45 mM Tris-HCl, $173 \mathrm{mM}$ glycerine and $0.1 \%$ w/v SDS). Nitrocellulose membranes were transiently 
stained with $0.1 \%$ Ponceau solution in $1 \%(\mathrm{v} / \mathrm{v})$ glacial acetic acid until protein bands were visible. The membranes were distained using distilled water and air dried followed by blocking with $5 \%(\mathrm{w} / \mathrm{v})$ low fat milk powder in Tris-Buffer Saline (TBS) for $1 \mathrm{~h}$. Tri-buffer saline was prepared by mixing $0.224 \%$ (w/v) Tris, $1.16 \%(w / v) ~ N a C l$ and adjusted to $\mathrm{pH} 7.4$ using $\mathrm{HCl}$. The membranes were washed three times in TBS for $5 \mathrm{~min}$ and incubated overnight with 10 $\mu \mathrm{g} . \mathrm{ml}^{-1}$ of primary antibody in $0.5 \%(\mathrm{w} / \mathrm{v}) \mathrm{BSA}-\mathrm{TBS}$ at room temperature with gentle agitation. Membranes were then washed twice with TBS for $5 \mathrm{~min}$ and incubated for $1 \mathrm{~h}$ in secondary antibody HRPO conjugate (rabbit anti-chicken IgY-horse radish peroxidase HRPO conjugate) in $0.5 \%$ (w/v) BSATBS. Nitrocellulose membranes were washed thrice for $5 \mathrm{~min}$ and then immersed in 4-chloro-1-naphthol$\mathrm{H}_{2} \mathrm{O}_{2}$ substrate solution containing $0.06 \%$ (w/v) 4chloro-1-naphthol, $0.1 \%(\mathrm{v} / \mathrm{v})$ methanol and $0.0015 \%$ (v/v) $\mathrm{H}_{2} \mathrm{O}_{2}$ in TBS. After substrate solution treatment, membranes were kept in the dark until bands were clearly visible, washed in distilled water and air dried for further analysis.

\section{Data Analysis}

Analysis Of Variance (ANOVA) was used to analyze the reactivity of the five different antibodies against the fungal isolates of $D$. pinea, $F$. circinatum and $F$. oxysporum. Significant differences between the treatments were determined using Duncan and Bonferroni test. Means from the absorbance obtained from each reaction were included in the differential values.

\section{Results and Discussion}

\section{SDS-PAGE Analysis and Purification of Proteins from Different Fungal Isolates and Antigens}

According to the analysis of protein banding profile, unique and similar bands were observed as similarities or differences according to pathogens. Similar protein band profile in mycelium-soluble antigens of $D$. pinea was observed where unique and prominent bands were observed at approximately 34 $\mathrm{kDa}$ and $39 \mathrm{kDa}$, which did not appear in any lanes of $F$. circinatum and $F$. oxysporum (Fig. 2, lane 2-4). When comparing protein bands for Fusarium spp., a unique protein band running at approximately $20 \mathrm{kDa}$ was observed for $F$. oxysporum. However, in all Fusarium spp. isolates, a protein band was found running similar and prominent in a region of $45 \mathrm{kDa}$ (Fig. 2, lane 5-10). Results indicated that, antigen expression was not consistent between isolates, as some proteins were degraded and disappeared during profiling probably due to preparation protocols or storage.
There was band similarities between $D$. pinea and $F$. oxysporum isolates, while $F$. circinatum showed a large number of prominent and different protein profiles between its isolates (Fig. 2, lane 5).

The analysis of exo-antigens showed no band development even when more sensitive stains such as silver or aureole staining were used. Results suggest that, the unique proteins identified in this study for each pathogen can be used for immunization or selection of unique monoclonal antibodies. Although, some proteins had similar sizes, variation in a wide range of banding profile was also observed among these pathogens. Gan et al. (1997) also reported the identification of unique proteins for the development of more specific antibodies for immunization against fungal pathogens. Earlier similar findings were made by (Kitagawa et al., 1989; Holtz et al., 1994; Gan et al., 1997) using different Fusarium pathogens and strains of Thielaviopsis basicola. Biazon et al. (2006) also identified common antigens using unique protein profiles from eight strains of $F$. verticillioides.

The unique proteins from $D$. pinea, $F$. oxysporum and $F$. circinatum were further purified for antibody production. A pure protein was obtained (Fig. 2B (i), lane 5), which was then intensified using BSA samples of known concentration $\left(50 \mu \mathrm{g} \cdot \mathrm{ml}^{-1}\right)$ (Fig. 2B (ii), lane $8)$. BSA standards were also used in other studies to achieve high quality products of unique proteins purified for assessing immunoaffinity and antibody production (Balkani et al., 2016; Raoufinia et al., 2016).

\section{Antibody Production, Reactivity Towards Antigens and Cross-Reactivity Test}

Antibody production after the first immunization was observed from the third week, which was common among all sets of antibodies. Isolates from $D$. pinea, $F$. circinatum and $F$. oxysporum with most number of protein bands and consistency on the patterns with different antigen preparation were selected, similar to report by (Biazon et al., 2006). Isolates of $F$. circinatum showed more reactivity towards anti- $F$. circinatum antibodies (Fig. 3, B4 and B5). The absorbance reading between different $F$. circinatum isolates ranged between 0.510 to 0.868 . Anti- $F$. oxysporum antibodies reactivity was relatively similar among the different isolates used, but with least reactivity in one of the isolates observed at absorbance value of 0.703 (Fig. 3, C4). Results obtained showed that the reactivity of anti- $D$. pinea antibodies was relatively low since the highest absorbance value obtained was 0.650 (Fig. 3, A1). Furthermore, the results also indicated that, the anti- $F$. oxysporum antibodies were the most reactive antibodies according to the highest absorbance values obtained. 

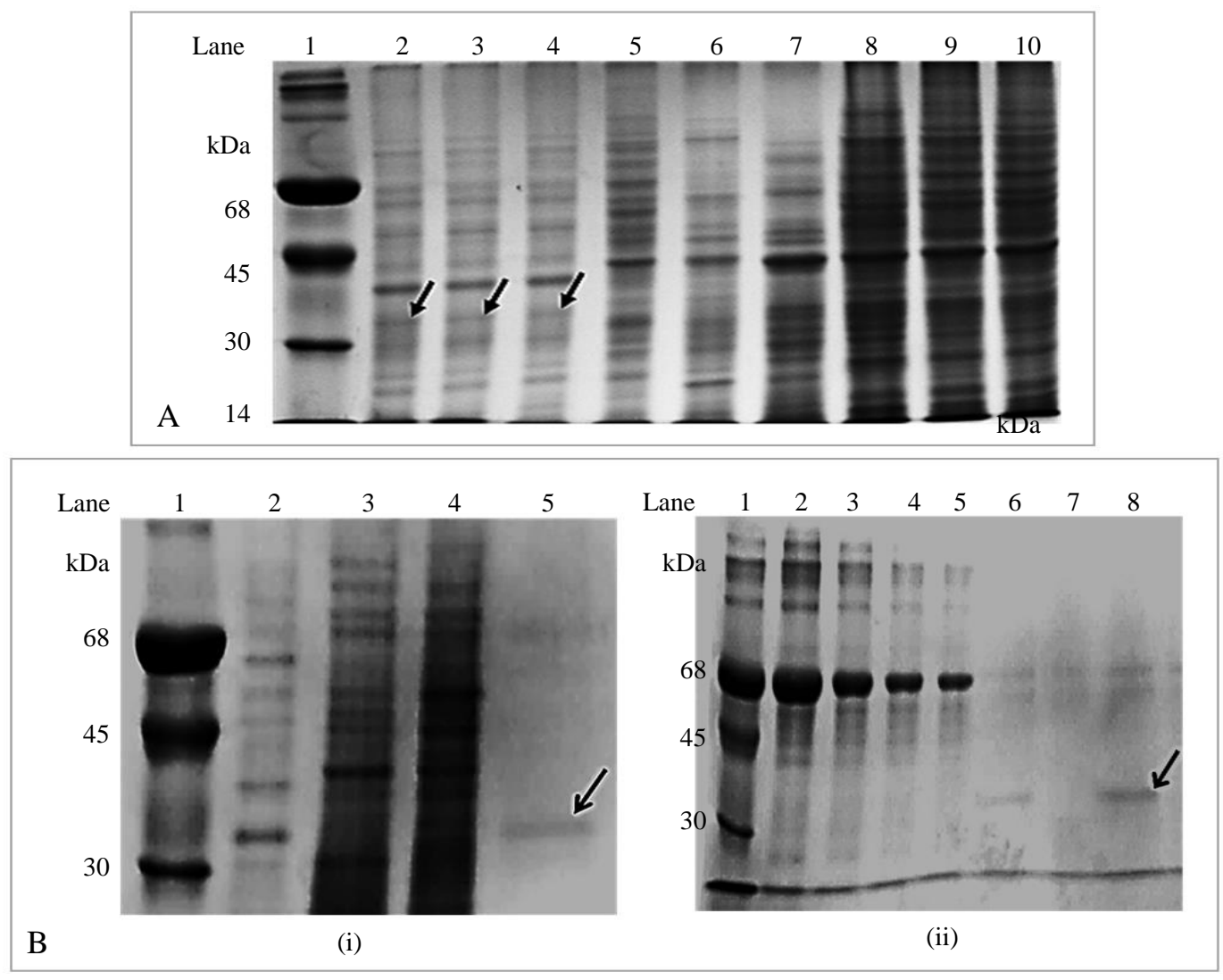

Fig. 2: Comparison of protein content from three isolates of $D$. pinea, F. circinatum and F. oxysporum analysed through $10 \%$ reducing SDS-PAGE. Lane 1- Molecular Weight Marker (MWM); lane 2-4- D. pinea isolates; lane 5-7- F. circinatum; lane 8-10- F. oxysporum. Arrow points to bands of interest that were further purified (A). Determination of purity and concentration of $D$. pinea-34 kDa protein by electro-elution. Initial purification: Lane 1- MWM; lane 2- D. pinea 16; lane 3- F. circinatum 3578; lane 4- F. oxysporum 776; lane 5- D. pinea $34 \mathrm{kDa}$ protein. Last purification: Lane 1- MWM; Lane 2- BSA 1 mg.ml ${ }^{-1}$; lane 3-

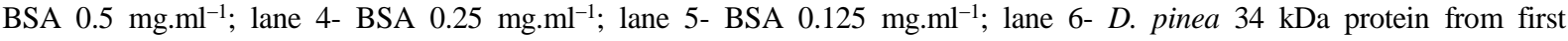
purification; lane 7- D. pinea $34 \mathrm{kDa}$ protein second purification; and lane $8-D$. pinea $34 \mathrm{kDa}$ protein third purification

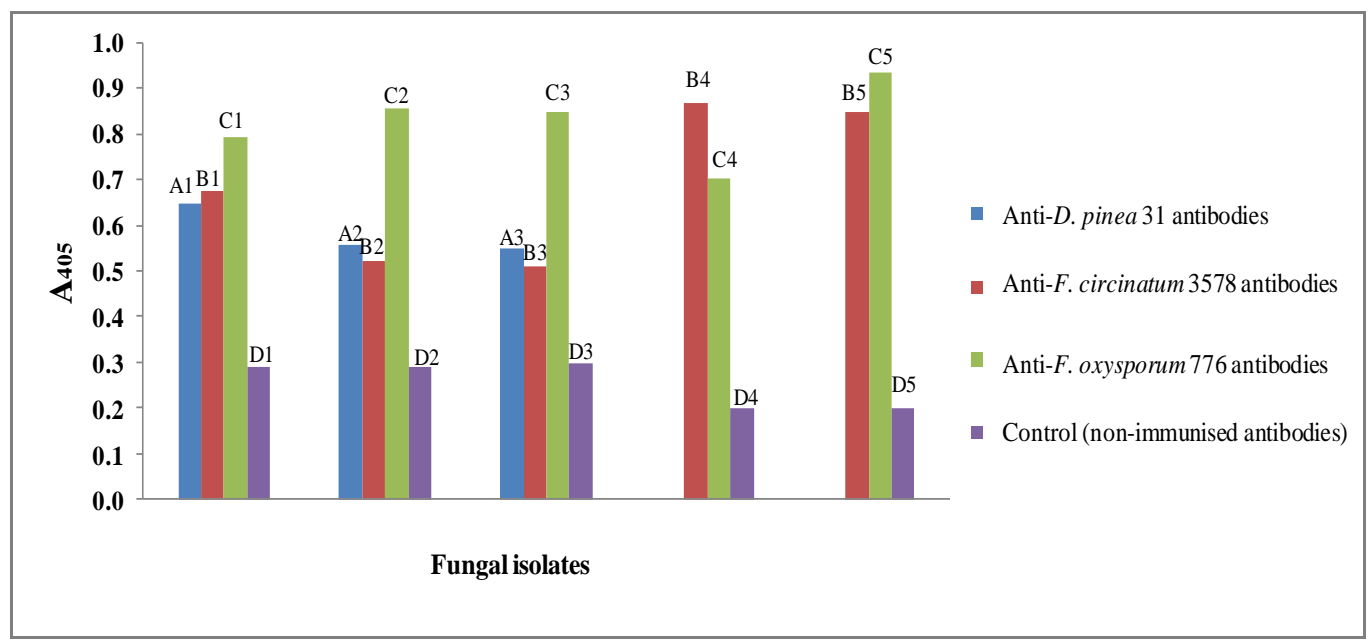

Fig. 3: Evaluation of anti- $D$. pinea, anti- $F$. circinatum and anti- $F$. oxysporum antibody reactivity against antigen isolates for the corresponding pathogens. Antigens $\left(100 \mu \mathrm{g} \cdot \mathrm{ml}^{-1}\right)$ isolated from D. pinea (A1-A3), isolates of F. circinatum (B1-B5) and isolates for $F$. oxysporum (C1-C5) 


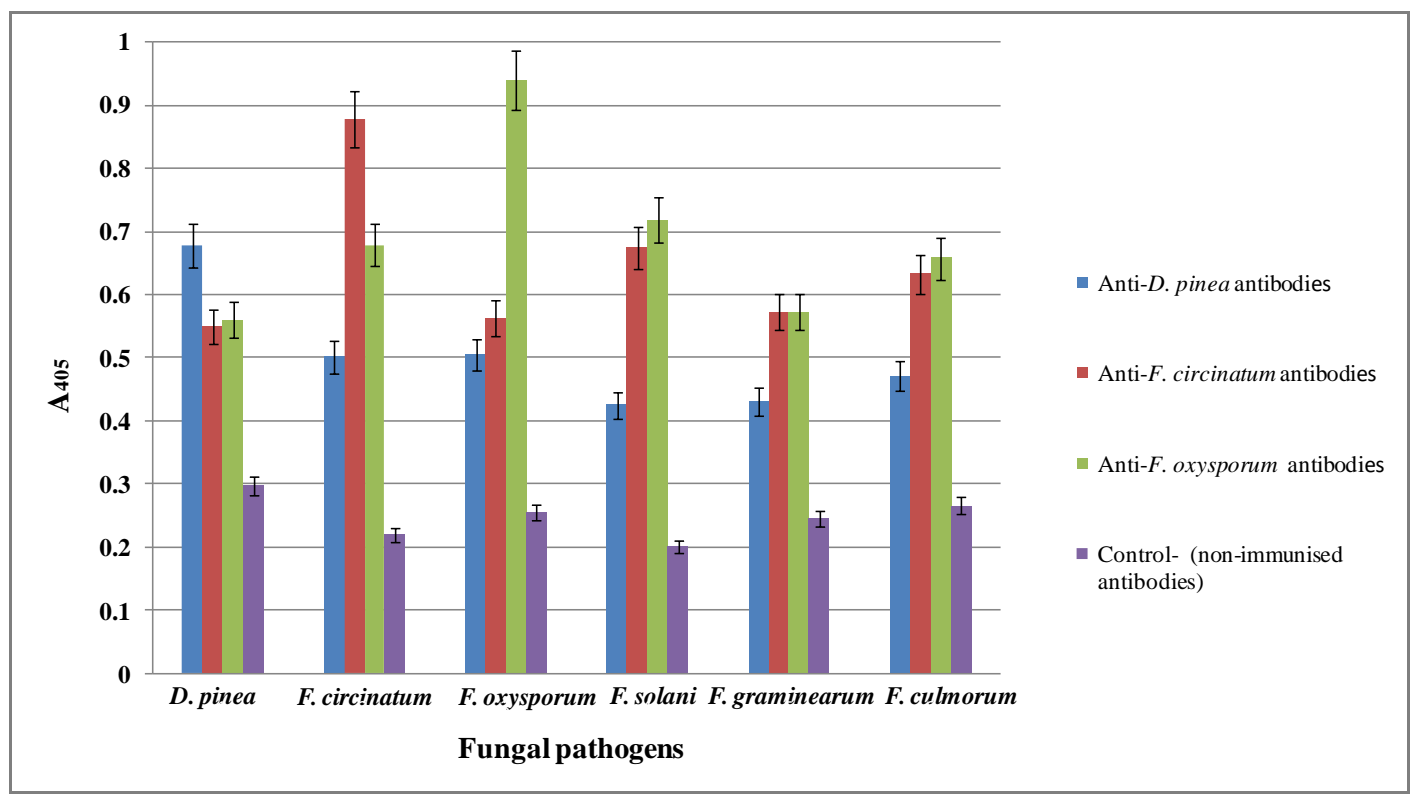

Fig. 4: Evaluation of anti- $D$. pinea, anti- $F$. circinatum and anti- $F$. oxysporum antibody cross-reactivity using indirect ELISA

The antibodies developed against mycelium-soluble antigens for $D$. pinea, $F$. circinatum and $F$. oxysporum showed more reactivity and specificity than antigen- $F$. circinatum exo- and anti- $D$. pinea antibodies. Although, cross-reactivity of anti- $D$. pinea antibodies with antigens from other fungal species was observed, this was minimal (Fig. 4). Anti-F. circinatum antibodies were more reactive towards antigens isolated from $F$. circinatum with most cross-reactivity observed with $F$. solani, F. culmorum, $F$. graminearum and $F$. oxysporum antigens, respectively. It should be noted that, positive reactions gave absorbance reading that were high enough to separate them from the cross-reactive reaction. With further developments where more cross-reactivity tests can be evaluated, cut-off values for each antibody specificity can be determined. On average, the absorbance reading for the detection of $F$. circinatum was 0.278 , higher than those of non-specific reactions. A similar trend was observed for anti- $F$. oxysporum antibodies where more reactivity was observed towards $F$. oxysporum antigens. Cross-reactivity was relatively high towards $F$. solani, $F$. circinatum and $F$. culmorum, but the absorbance reading for the specific antigen detected was 0.303 units higher than that of non-specific antigens.

A significant variation ( $p$-value $<0.0001$ ) was obtained from the evaluation of immunochemical similarities between isolates of the same fungal pathogens compared to the isolates from other fungal pathogens indicated on Fig. 3. The reactivity of different antibodies with different $F$. circinatum isolates indicated variation in the immunochemical composition of these isolates. As indicated in the ELISA shown in Fig. 3 and 4, there was immunochemical differences emanating from the reactivity of antibodies with the isolates in $F$. circinatum and $F$. oxysporum, but no reactivity of different antibodies with isolates of $D$. pinea. However, as expected, most reactivity was observed from anti- $D$. pinea antibodies with its isolates. Furthermore, anti- $F$. circinatum exo- and anti- $D$. pinea $34 \mathrm{kDa}$ antibodies were the least reactive antibodies and showed non-specific binding.

\section{Western Blot Analysis}

The analysis of antibody reactivity with different antigens blotted on nitrocellulose membrane indicated common antigens between different fungal pathogens. When anti- $F$. circinatum antibodies were used for detection of different fungal pathogens, results indicated that they cross-reacted with antigens larger than $45 \mathrm{kDa}$ for D. pinea and F. oxysporum (Fig. 5).

In $F$. circinatum isolates, antibodies reacted with 24 $\mathrm{kDa}$ antigens but, the immuno-dominant antigens were observed from $35 \mathrm{kDa}$ and above. Common antigen between $F$. circinatum isolates were observed at approximately $67 \mathrm{kDa}, 58 \mathrm{kDa}, 45 \mathrm{kDa}, 34 \mathrm{kDa}$ and 35 $\mathrm{kDa}$ as indicated on Fig. 4 (lane 6-8). However, prominent antigens were observed at $68 \mathrm{kDa}$ for only $F$. circinatum (Fig. 5, lane 6 and 7). These observations suggests that the common antigens between the $F$. circinatum isolates at $45 \mathrm{kDa}$ might be the prominent protein observed on the SDS-PAGE (Fig. 4), also common between $F$. circinatum and $F$. oxysporum. Anti$F$. circinatum antibodies did not bind the $45 \mathrm{kDa}$ protein from $F$. oxysporum. A common antigen at $67 \mathrm{kDa}$ observed on the nitrocellulose membrane was also a common protein on the SDS-PAGE observed between the $F$. circinatum isolates. 


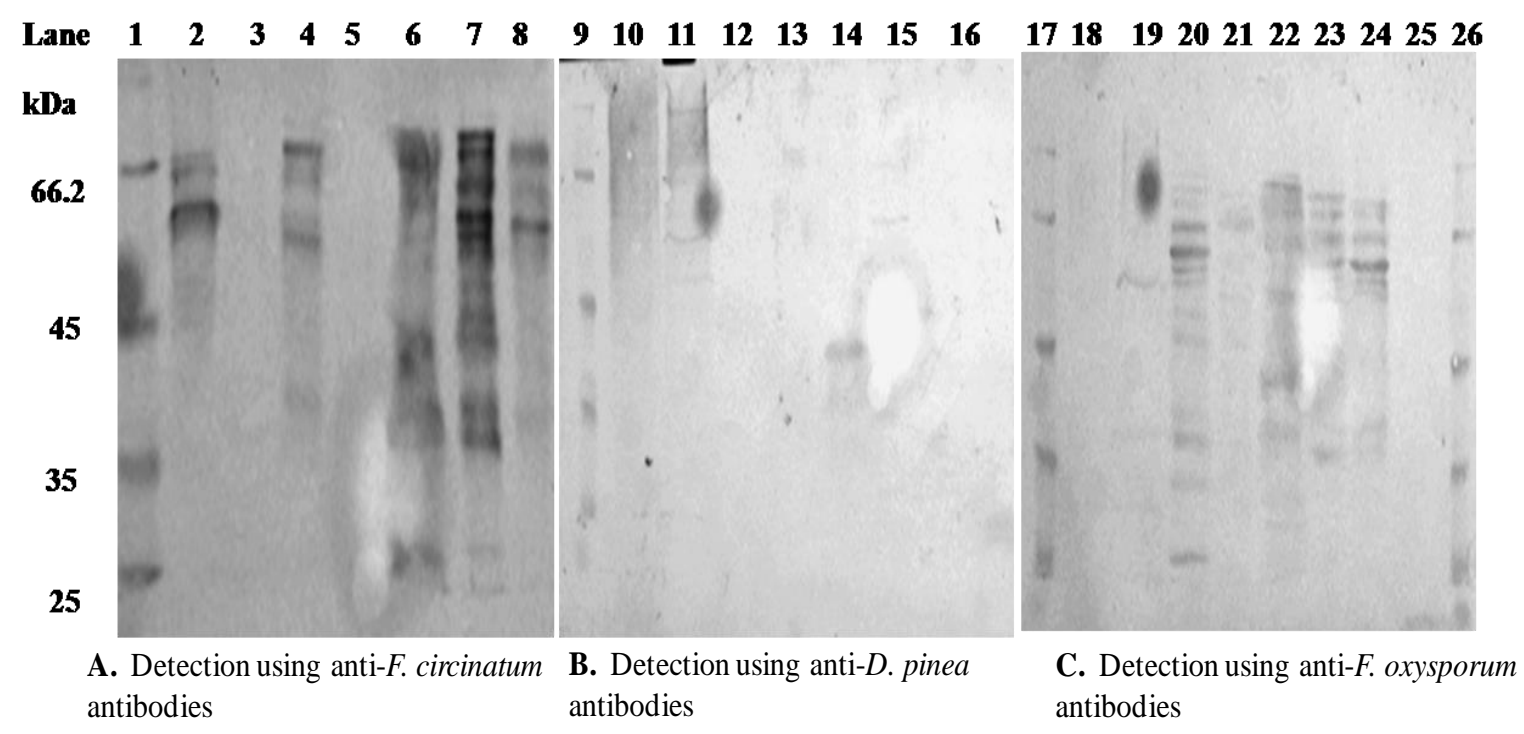

Fig. 5: Western blotting analysis of cross-reactivity of different antibodies raised to mycelium soluble-antigens from $D$. pinea, $F$. circinatum and $F$. oxysporum. (A). Detection using anti- $F$. circinatum antibodies; lane 1, MWM; lane 2, D. pinea 31; lane 3, $D$. pinea 16 ; lane $4, F$. oxysporum 776 ; lane $5, F$. oxysporum 1861 ; lane $6, F$. circinatum 3578 ; lane $7, F$. circinatum 3580 ; lane 8, F. circinatum 3579. (B). Detection using anti-D. pinea antibodies, Lane 9, MWM; lane, 10 D. pinea 31; lane 11, D. pinea 16 ; lane $12, F$. circinatum 3578 ; lane $13, F$. circinatum 3580 ; lane $14, F$. oxysporum 776 ; lane $15, F$. oxysporum 1861 ; lane $16, F$. oxysporum 1858. (C). Detection using anti-F. oxysporum antibodies; lane 17, MWM; lane 18, D. pinea 31; lane 19, D. pinea 16 ; lane $20, F$. circinatum 3578 ; lane $21, F$. circinatum $3580 ;$ lane $22, F$. oxysporum 776 ; lane $23, F$. oxysporum 1861 ; lane $24, F$. oxysporum 1858 ; lane 25 , contains only nutrient broth as control; lane 26 , MWM

The most reactivity showed by the development of daker bands on the nitrocellulose membrane was observed in $F$. circinatum isolates, probably due to overloading (lane 6-8, Fig. 4). Cross-reactivity of anti- $F$. circinatum antibodies with $D$. pinea and $F$. oxysporum was observed in lane 2 and 4 (Fig. 5), most notably at 67,65 and $58 \mathrm{kDa}$ with $D$. pinea and $67 \mathrm{kDa}$ as well as $58 \mathrm{kDa}$ with $F$. oxysporum, respectively.

The reactivity of anti- $D$. pinea antibodies was not as prominent as that observed for anti- $F$. circinatum antibodies. These findings were similar to the observations made in the ELISA on Fig. 3 and 4. The 56 $\mathrm{kDa}$ antigen observed on Fig. 3 and 4 had the same size as one of the proteins that were common among $D$. pinea isolates indicated by SDS-PAGE (Fig. 5A) with both specific and non-specific band cross-reactivity with some of the $F$. oxysporum isolates. Lastly, the anti- $F$. oxysporum antibodies reacted strongly with all $F$. oxysporum isolates, with common antigens observed at 60, 58 and $53 \mathrm{kDa}$.

Overall, these findings indicated that, antibodies against mycelium-soluble antigens were the most immuno-reactive. Earlier reports with varying findings indicated that immunizing with mycelium-soluble antigens resulted in more reactive and less specific antibodies developed against exo-antigens, with other reporting increased specificity (Brill et al., 1994; Gan et al., 1997; Hitchcock et al., 1997; Hayashi et al.,
1998). In the current study reactivity obtained with anti- $F$. circinatum exo-antigen antibodies showed no significant difference when these antibodies reacted with other Fusarium species and no increased specificity was observed which is in contrast with the observations made by (Gan et al., 1997). This informed the selection of antibodies to use for cross-reactivity tests in ELISA and western blotting.

Furthermore, comparing the cross-reactivity amongst anti- $D$. pinea, anti- $F$. circinatum and anti- $F$. oxysporum antibodies showed that anti- $D$. pinea antibodies were less reactive with other pathogens when analysed with both ELISA and western blots. Antibodies against $F$. circinatum can be characterised as genus-specific antibodies since these showed strong reactivity with other fungi of the same genus. However, these antibodies were more reactive towards their corresponding antigen indicated by the higher absorbance reading and development of multiple bands on the western blot when detecting $F$. circinatum isolates, in contrast with the few bands that developed for the detection of $D$. pinea and $F$. oxysporum isolates with the same antibodies. Reactivity of anti- $F$. oxysporum antibodies were more directed to $F$. oxysporum antigens as expected, but the specificity of these antibodies can also be characterised as genus specific. Such antibody specificity has also been observed in other studies that used both monoclonal and polyclonal antibodies for 
fungal detection (Arie et al., 1998; Bossi and Dewey, 1992; Thornton et al., 2002; Schmechel et al., 2003).

Other studies have reported similar trend of antibody reactivity where it was concluded that more cross-reactivity occurs between fungi from the same genera because of common epitopes present within the same genus as was also observed in the current study (Biazon et al., 2006). Findings made in this study showed that, antibodies obtained in the current study were not species-specific, showing cross-reactivity with pathogens from other genera. However, these antibodies were more reactive towards their corresponding antigens indicating their potential use for detection of $D$. pinea, $F$. circinatum and $F$. oxysporum followed by more validating tests such as PCR where necessary.

\section{Conclusion}

This study showed the presence of common antigens and development of antibodies from exo- and myceliumsoluble antigens as well as purified proteins from reducing SDS-PAGE probed against different fungal pathogens. Antibody reactivity evaluation using indirect ELISA showed cross-reactivity relationship between anti- $D$. pinea, anti- $F$. circinatum and anti- $F$. oxysporum antibodies. The development of these antibodies could be further tested to provide an easy and fast field test in identifying infections involving $F$. circinatum, $F$. oxysporum and D. pinea.

\section{Acknowledgement}

The National Research Foundation of South Africa, the University of KwaZulu-Natal and the South African pine growers are acknowledged for financial support of this study. Prof M.D. Laing is acknowledged for supervision of the study and sharing his expertise in Plant Pathology. Prof. T.H.T. Coetzer is acknowledged for supervision of the study and sharing her expertise in Biochemistry. South African pulp and paper industry is acknowledged providing the seedlings used in the study. Prof. T. Cotinho is acknowledge for providing Fusarium and D. pinea isolates. Fusarium working team is acknowledged for sharing their expertise in field work and disease progression. University of KwaZulu-Natal Biochemistry and Plant Pathology students and staff members are acknowledged for the technical support and different contributions towards the success of the project.

\section{Funding Information}

This work was supported by the National Research Foundation of South Africa, the University of KwaZuluNatal and the South African pine growers.

\section{Author's Contributions}

Phumzile Mkhize: Conducted the experiments and data analysis.

Phetole Mangena: Contributed in the preparation, development and publication of this manuscript.

\section{Ethics}

The authors declare their responsibility for any ethical issues that may arise after the publication of this manuscript.

\section{References}

Adesina, M. F., Grosch, R., Lembke, A., Vatchev, T. D., \& Smalla, K. (2009). In vitro antagonists of Rhizoctonia solani tested on lettuce: rhizosphere competence, biocontrol efficiency and rhizosphere microbial community response. FEMS microbiology ecology, 69(1), 62-74.

Arie, T., Gouthu, S., Shimazaki, S., Kamakura, T., Kimura, M., Inoue, M., ... \& Yamaguchi, I. (1998). Immunological Detection of endo Polygalacturonase Secretion by Fusarium oxyspoyum in Plant Tissue and Sequencing of Its Encoding Gene. Japanese Journal of Phytopathology, 64(1), 7-15.

Bailey, K. L., \& Lazarovits, G. (2003). Suppressing soilborne diseases with residue management and organic amendments. Soil and tillage research, 72(2), 169-180.

Balkani, S., Shamekhi, S., Raoufinia, R., Parvan, R., \& Abdolalizadeh, J. (2016). Purification and characterization of bovine serum albumin using chromatographic method. Advanced pharmaceutical bulletin, 6(4), 651.

Beukes, I., Rose, L. J., Shephard, G. S., Flett, B. C., \& Viljoen, A. (2017). Mycotoxigenic Fusarium species associated with grain crops in South Africa-A review. South African Journal of Science, 113(3-4), $1-12$.

Biazon, L., Meirelles, P. G., Ono, M. A., Itano, E. N., Taniwaki, M. H., Sugiura, Y., ... \& Ono, E. Y. (2006). Development of polyclonal antibodies against Fusarium verticillioides exoantigens. Food and agricultural immunology, 17(1), 69-77.

Bossi, R., \& Dewey, F. M. (1992). Development of a monoclonal antibody-based immunodetection assay for Botrytis cinerea. Plant pathology, 41(4), 472-482.

Brill, L. M., McClary, R. D., \& Sinclair, J. B. (1994). Analysis of two ELISA formats and antigen preparations using polyclonal antibodies against Phomopsis longicolla. Phytopathology, 84(2), 173-179. 
Bubici, G., Kaushal, M., Prigigallo, M. I., Gómez-Lama Cabanás, C., \& Mercado-Blanco, J. (2019). Biological control agents against Fusarium wilt of banana. Frontiers in microbiology, 10, 616.

Gan, Z., Marquardt, R. R., Abramson, D., \& Clear, R. M. (1997). The characterization of chicken antibodies raised against Fusarium spp. by enzymelinked immunosorbent assay and immunoblotting. International journal of food microbiology, 38(2-3), 191-200.

Gordon, T. R., Swett, C. L., \& Wingfield, M. J. (2015). Management of Fusarium diseases affecting conifers. Crop protection, 73, 28-39.

Hayashi, Y., Arie, T., Yoneyama, K., \& Yamaguchi, I. (1998). Characterization of the antigenic determinant on Fusarium oxysporum recognizedby a genus-specific monoclonal antibody. The Journal of general and applied microbiology, 44(1), 43-47.

Hitchcock, P., Gray, T. R., \& Frankland, J. C. (1997). Production of a monoclonal antibody specific to Mycena galopus mycelium. Mycological Research, 101(9), 1051-1059.

Holtz, B. A., Karu, A. E., \& Weinhold, A. R. (1994). Enzyme-linked immunosorbent assay for detection of Thielaviopsis basicola. Phytopathology, 84(9), 977-983.

Kuzdraliński, A., Kot, A., Szczerba, H., Nowak, M., \& Muszyńska, M. (2017). A review of conventional PCR assays for the detection of selected phytopathogens of wheat. Journal of Molecular Microbiology and Biotechnology, 27(3), 175-189.

Kitagawa, T., Sakamoto, Y., Furumi, K., \& Ogura, H. (1989). Novel enzyme immunoassays for specific detection of Fusarium oxysporum f. sp. cucumerinum and for general detection of various Fusarium species. Phytopathology, 79(2), 162-165.

Laemmli, U. K. (1970). Cleavage of structural proteins during the assembly of the head of bacteriophage T4. nature, 227(5259), 680-685.

Nelson, P. E., Dignani, M. C., \& Anaissie, E. J. (1994). Taxonomy, biology and clinical aspects of Fusarium species. Clinical microbiology reviews, 7(4), 479-504.
Polson, A., Coetzer, T., Kruger, J., Von Maltzahn, E., \& Van der Merwe, K. J. (1985). Improvements in the isolation of $\mathrm{IgY}$ from the yolks of eggs laid by immunized hens. Immunological investigations, 14(4), 323-327.

Raoufinia, R., Mota, A., Nozari, S., Aghebati Maleki, L., Balkani, S., \& Abdolalizadeh, J. (2016). A methodological approach for purification and characterization of human serum albumin. Journal of Immunoassay and Immunochemistry, 37(6), 623-635.

Schmechel, D., Gorny, R. L., Simpson, J. P., Reponen, T., Grinshpun, S. A., \& Lewis, D. M. (2003). Limitations of monoclonal antibodies for monitoring of fungal aerosols using Penicillium brevicompactum as a model fungus. Journal of immunological methods, 283(1-2), 235-245.

Springer, J., Walther, G., Rickerts, V., Hamprecht, A., Willinger, B., Teschner, D., ... \& Loeffler, J. (2019). Detection of Fusarium Species in Clinical Specimens by Probe-Based Real-Time PCR. Journal of Fungi, 5(4), 105.

Storer, A. J., Wood, D. L., \& Gordon, T. R. (2002). The epidemiology of pitch canker of Monterey pine in California. Forest Science, 48(4), 694-700.

Sue, M. J., Yeap, S. K., Omar, A. R., \& Tan, S. W. (2014). Application of PCR-ELISA in molecular diagnosis. BioMed research international, 2014.

Thornton, C. R., Pitt, D., Wakley, G. E., \& Talbot, N. J. (2002). Production of a monoclonal antibody specific to the genus Trichoderma and closely related fungi and its use to detect Trichoderma spp. in naturally infested composts. Microbiology, 148(5), 1263-1279.

Towbin, H., Staehelin, T., \& Gordon, J. (1979). Electrophoretic transfer of proteins from polyacrylamide gels to nitrocellulose sheets: procedure and some applications. Proceedings of the National Academy of Sciences, 76(9), 4350-4354.

Zhao, X., Lin, C. W., Wang, J., \& Oh, D. H. (2014). Advances in rapid detection methods for foodborne pathogens. J. Microbiol. Biotechnol, 24(3), 297-312. 